Inventions of the Skin 
Edinburgh Critical Studies in Renaissance Culture

Series Editor: Lorna Hutson

Titles available in the series:

Open Subjects: English Renaissance Republicans, Modern Selfhoods and the Virtue of Vulnerability

James Kuzner

$9780748642533 \mathrm{Hbk}$

The Phantom of Chance: From Fortune to Randomness in SeventeenthCentury French Literature

John D. Lyons

$9780748645152 \mathrm{Hbk}$

Don Quixote in the Archives: Madness and Literature in Early Modern Spain

Dale Shuger

$9780748644636 \mathrm{Hbk}$

Untutored Lines: The Making of the English Epyllion

William P. Weaver

$9780748644650 \mathrm{Hbk}$

The Girlhood of Shakespeare's Sisters: Gender, Transgression, Adolescence

Jennifer Higginbotham

$9780748655908 \mathrm{Hbk}$

Friendship's Shadows: Women's Friendship and the Politics of Betrayal in England, 1640-1705

Penelope Anderson

$9780748655823 \mathrm{Hbk}$

Inventions of the Skin: The Painted Body in Early English Drama, 1400-1642

Andrea Ria Stevens

$9780748670499 \mathrm{Hbk}$

Performing Economic Thought: English Drama and Mercantile Writing, 1600-1642

Bradley D. Ryner

$9780748684656 \mathrm{Hbk}$

Visit the Edinburgh Critical Studies in Renaissance Culture website at www.euppublishing.com/series/ecsrc 


\section{Inventions of the Skin}

The Painted Body in Early English Drama, 1400-1642

Andrea Ria Stevens 
(C) Andrea Ria Stevens, 2013

Edinburgh University Press Ltd

22 George Square, Edinburgh EH8 9LF

www.euppublishing.com

Typeset in 10.5/13 Adobe Sabon by Servis Filmsetting Ltd, Stockport, Cheshire, and printed and bound in Great Britain by CPI Group (UK) Ltd, Croydon, CR0 4YY

A CIP record for this book is available from the British Library

ISBN 9780748670499 (hardback)

ISBN 9780748670505 (webready PDF)

ISBN 9780748670512 (epub)

The right of Andrea Ria Stevens to be identified as author of this work has been asserted in accordance with the Copyright, Designs and Patents Act 1988. 